\title{
New Records for the Aesculapian Snake (Zamenis longissimus) (Reptilia: Colubridae) in Romanian Moldova
}

\author{
Alexandru STRUGARIU ${ }^{1,}$, Iulian GHERGHEL ${ }^{2}$, Tiberiu C. \\ SAHLEAN ${ }^{3}$, Eugen UNGUREANU ${ }^{1}$, Ștefan R. ZAMFIRESCU ${ }^{1}$
}

\begin{abstract}
${ }^{1}$ Faculty of Biology, "Alexandru Ioan Cuza” University of Iași, Blvd. Carol 1 nr. 20A, 700505, Iași, Romania

${ }^{2}$ Department of Biology, Case Western Reserve University, 2080 Adelbert Road, 44106, Cleveland, Ohio, USA

3"Grigore Antipa" National Museum of Natural History, Șos. Kiseleff nr. 1, 011341, Bucharest, Romania. *corresponding author, e-mail: alex.strugariu@gmail.com
\end{abstract}

Received: February 8, 2016; Accepted: April 18, 2016; Available online: June 29, 2016; Printed: June 30, 2016

\begin{abstract}
The Aesculapian snake (Zamenis longissimus) is a widespread colubrid species, being present in much of central and southern Europe, with isolated populations occuring as far east as Iran. In Romania, the species is known from most of the country's regions, although it has been reported from very few areas from the Moldova region (eastern and north-eastern Romania). Here we present three new records for $Z$. longissimus in Romanian Moldova, including the first record for the species in Botoșani County, the north-easternmost region of Romania.
\end{abstract}

Key words: Reptiles, distribution, deciduous forests, Botoşani County, Romania.

The Aesculapian snake, Zamenis longissimus (Laurenti, 1768), is one of the largest Eurasian colubrid species, sometimes exceeding two meters in length (Böhme, 1993). The species exhibits a broad distribution range, spanning from northern Spain in the southwest, through most of central, southern and south-eastern Europe, and western Ukraine in the east; more isolated populations naturally occur as far east as Russia, Turkey, and Iran (Böhme, 1993; Ananjeva et al., 2006; Musilova et al., 2007). Z. longissimus is officially considered extinct in Denmark, while introduced individuals in the United Kingdom have successfully established persisting populations (Musilova et al., 2007 and references therein). Z. longissimus is a semi-arboreal and relatively thermophile species, and is associated with warm, but moderately humid, deciduous or mixed forests, scrubland, forest-steppes or rocky but well vegetated areas (e.g. Gomille, 2002). Due to its broad range, the species is listed as Least Concern in the IUCN Red List (Agasyan et al., 2009). However, it is included in several national or regional red lists (Ananjeva et al., 2006) and, within the European Union, it is considered a species of community interest that requires strict protection (Annex 4 of the Habitat Directive).

In Romania, Z. longissimus has been recorded in all major regions of the country (Cogălniceanu et al., 2013), and it is listed as vulnerable in the national red data book of vertebrates (Iftime, 2005). Despite extensive herpetological surveys, in the historic region of Moldova (eastern and north-eastern Romania), Z. longissimus has only been recorded in a handful of localities from this region (Ghiurcă et al., 2005a,b; Strugariu et al., 2006, 2008; Gherghel et al., 2008; Strugariu \& Gherghel, 2008). 
During recent field surveys conducted in Romanian Moldova, Z. longissimus individuals were recorded in three localities not previously known to be inhabited by the species (Fig. 1). Specifically, on May 27 ${ }^{\text {th }}, 2012$, we observed a live adult female ( $>$ $100 \mathrm{~cm}$ total length) between the localities of Poieni and Bogata, near Natura2000 site ROSCI0318 Măgura Târgu Ocna, Bacău County (coordinates $46.2860^{\circ} \mathrm{N} ; 26.5645^{\circ} \mathrm{E}$, elevation: $318 \mathrm{~m}$ ASL) (Fig. 2A-B); the snake was partly hidden in a pile of branches, along the edge of a deciduous forest. A second live Z. longissimus individual was a young adult (ca. $100 \mathrm{~cm}$ total length) of unknown sex, found on May $6^{\text {th }}, 2013$, basking on the asphalt road near Slobozia and Dobrovăț localities, inside Natura2000 site ROSCI0135 Pădurea Bârnova - Repedea, Iași County (C. O. Manci, personal communication - coordinates: $47.0049^{\circ} \mathrm{N} ; 27.6652^{\circ} \mathrm{E}$; elevation: $330 \mathrm{~m}$ ASL)(Fig. 2C). Finally, on May $10^{\text {th }}, 2013$ we found a dead adult male $(>100 \mathrm{~cm}$ total length) Z. longissimus on a dirt road near Tudora, inside Natura2000 site ROSCI0076 Dealul Mare - Hârlău, Botoșani County $\left(47.5209^{\circ} \mathrm{N} ; 26.6762^{\circ}\right.$ E; elevation: 324 m ASL) (Fig. 2D-E). All these areas are characterized by hilly relief, with deciduous forests with beech, oak, hornbeam, alder, ash, elm, and willow, in various combinations (Chifu et al., 2014).

Z. longissimus has been previously recorded from Bacău and Iași counties ( 7 localities - Ghiurcă et al., 2005; and 3 localities - Strugariu et al., 2008, respectively), whereas we report the species for the first time from Botoșani County (the northeasternmost region of Romania). Furthermore, our observations from Iași and Botoșani counties represent only the 5th and 6th locality records for $Z$. longissimus in eastern

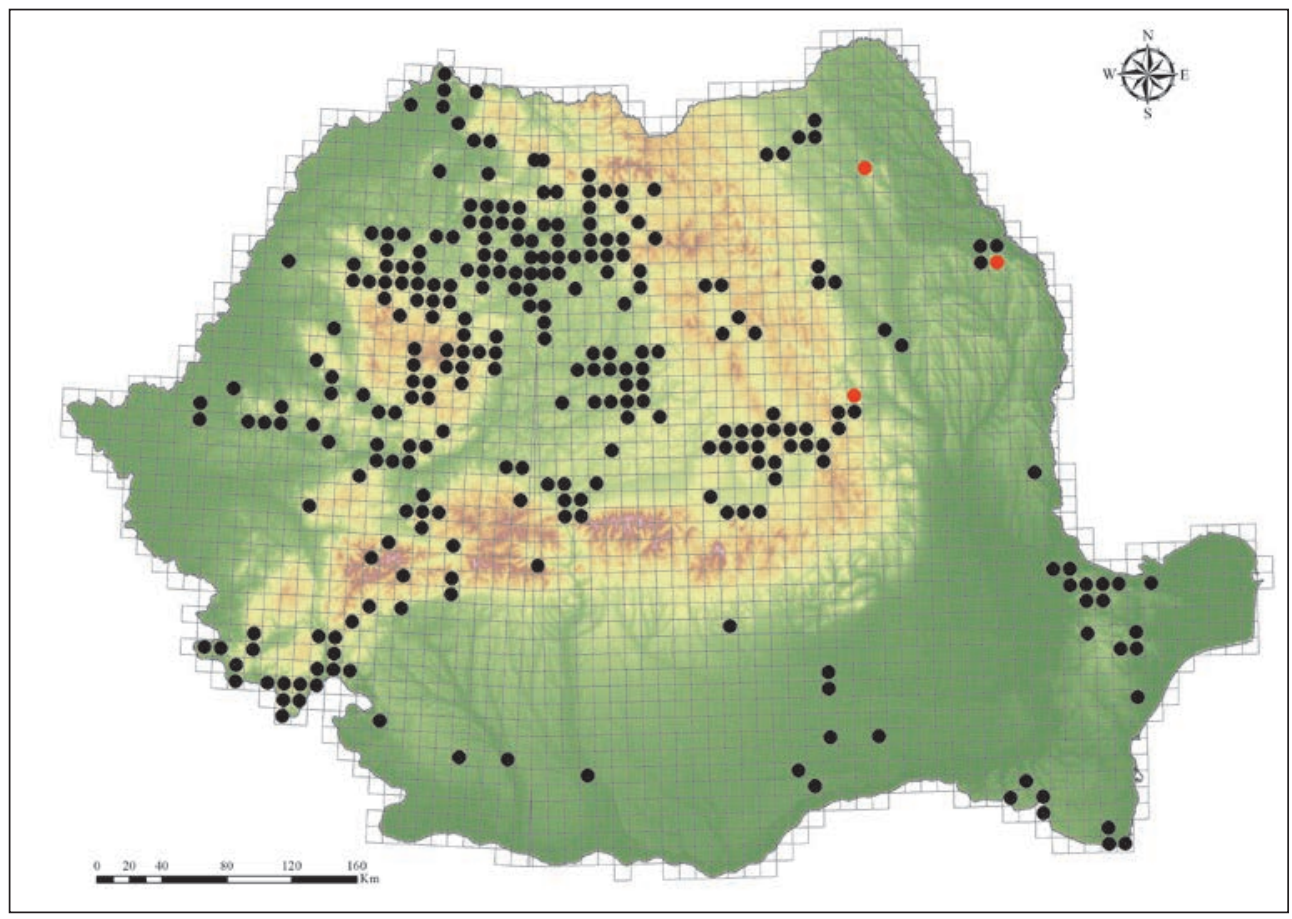

Fig. 1 - Updated distribution map for Zamenis longissimus in Romania. Map compiled using data from Cogălniceanu et al. (2013) (black dots) and the new locality records documented in the current paper (red dots). 

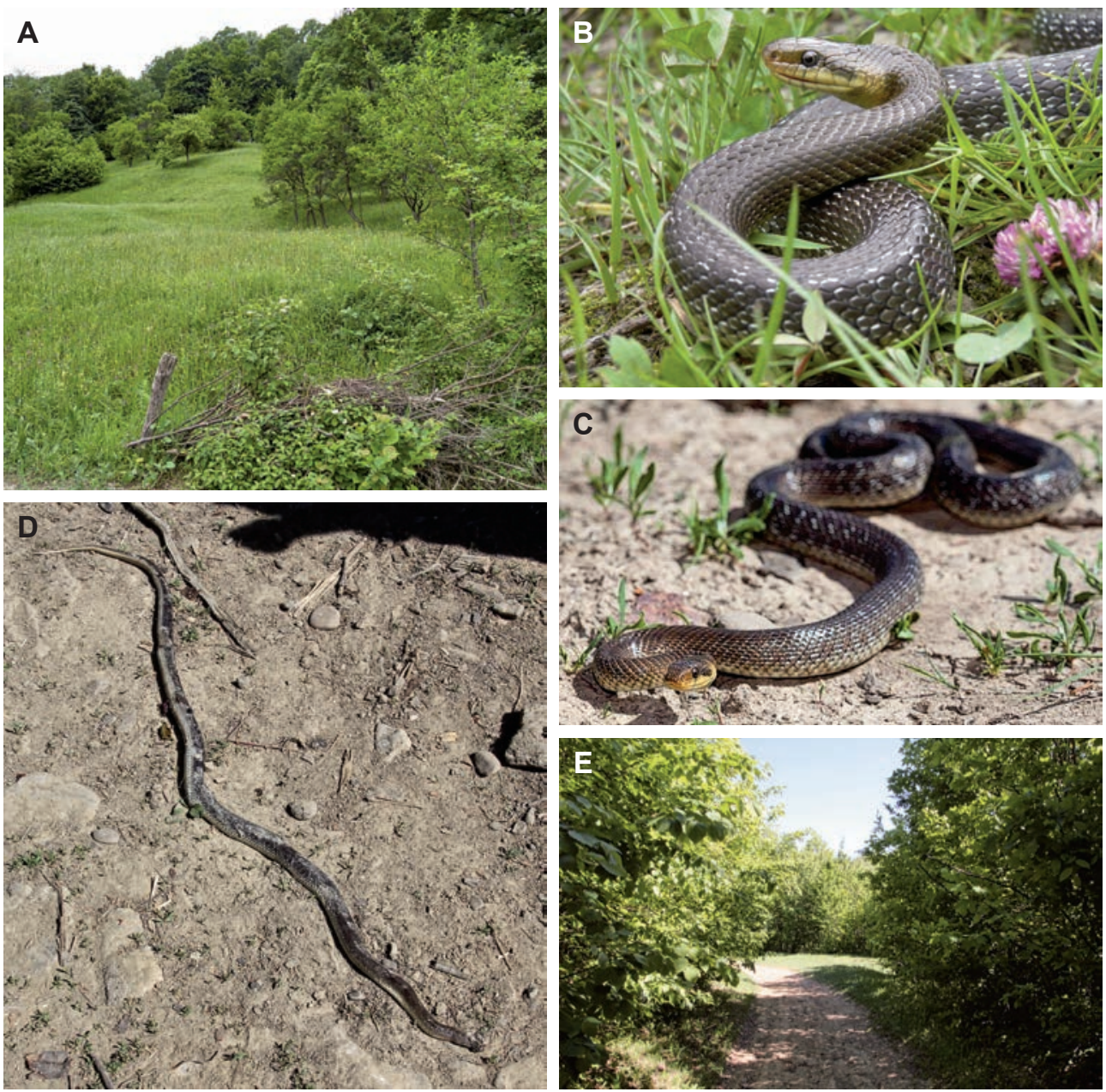

Fig. 2 - Habitats and individuals of Zamenis longissimus documented in the current paper: A and B Bacău County, between Poieni and Bogata (photo by Ș.R. Zamfirescu); C - Iași County, near Slobozia and Dobrovăț (photo courtesy of Cosmin O. Manci); D and E - Botoșani County, near Tudora (photo by Eugen Ungureanu).

Romanian Moldova (i.e. east of the Siret River: Strugariu \& Gherghel, 2008; Strugariu et al., 2008). Thus, our data sugests that $Z$. longissimus is probably more widespread in Romanian Moldova, occurring in most of the larger deciduous forests. The species is either very elusive or is present at low densities, which would explain the small number of records to date. Regardless of the scarce record data explanation, the species should be considered as threatened in this region of Romania, especially east of the Siret River, because of habitat alteration (i.e. deforestation and fragmentation of deciduous woodlands).

Our findings again highlight the necessity for further herpetofaunal surveys in Romanian Moldova with the purpose of completing the gaps in amphibian and reptile species distribution. Despite intense suverys being conducted throughout the 
country after the year 2000 (reviewed in Strugariu, 2014), remarkable herpetofaunal faunistical discoveries or range extensions continue to be made (e.g. impressive range extension for Pelobates syriacus - Székely et al., 2013; rediscovery of Eryx jaculus - Covaciu-Marcov et al., 2012; Sahlean et al., 2015). Potentially important tools that can be used prior to herpetological surveys are habitat suitability models and species distribution models, which help field researchers narrow their searches to areas known to be suitabile for target species (e.g. Sahlean et al., 2014, Gherghel \& Papeș, 2015).

We are grateful to dr. C.O. Manci (www.cosmln.nature4stock.com) for sharing with us his observation and images of the Aesculapian snake from Iași County, to Dr. A. Iftime and the anonymous reviewers for their useful comments on a previous draft of the manuscript. Field--work conducted in Bacău County in 2012, by AS and SRZ, was financed through the project "Servicii şi echipamente necesare pentru realizarea Sistemului Integrat de Management şi Conştientizare în România a Reţelei Natura 2000" (SINCRON) (POS Mediu axa 4). This paper was funded by the "Alexandru Ioan Cuza" University of Iași, through the project 06/3.12.2015, code: GI-2015-03, Grant Competition for Young Researchers of UAIC, to the first author.

\section{REFERENCES}

AGASYAN, A., A. AVCI., B. TUNIYEV, J. CRNOBRNJA-ISAILOVIC, P. LYMBERAKIS, C. ANDRÉN, D. COGĂLNICEANU, J. WIKLINSON, N. ANANJEVA, N. ÜZUM, N. ORLOV, R. PODLOUCKY, S. TUNIYEV, U. KAYA, W. BÖME, R. AJTIC, M. VOGRIN, C. CORTI, V. M. PÉREZ, P. SÁ-SOUSSA, M. CHEYLAN, J. PLEGUEZUELOS, B. BORCZYK, B. SCHMIDT, A. MEYER (2009) Zamenis longissimus. The IUCN Red List of Threatened Species, 2009: e.T157266A5065521.

ANANJEVA, N. B., N. I. ORLOV, R. G. KHALIKOV, I. S. DAREVSKY, S. A. RYABOV, A. BARABANOV (2006) The reptiles of Northern Eurasia: Taxonomic Diversity, Distribution, Conservation Status. Pensoft Publishing, Sofia.

BÖME, W. (1993) Äskulapnatter (Elaphe longissima Laurenti, 1768). Pp. 331-372. In: W. Böhme (ed.) Handbuch der Reptilien und Amphibien Europas. Wiesbaden, Aula Verlag. (in German)

CHIFU, T., I. IRIMIA, O. ZAMFIRESCU (2014) Diversitatea fitosociologică a vegetației României, vol. 3 - Vegetația pădurilor și tufișurilor, Iași, Institutul European, 552 pp. (in Romanian)

COGĂLNICEANU D., L. ROZYLOWICZ., P. SZÉKELYY, C. SAMOILÄ, F. STĂNESCU, M. TUDOR, D. SZÉKELY, R. IOSIF (2013) Diversity and distribution of reptiles in Romania. ZooKeys, 341: 49-76.

COVACIU-MARCOV, S.D., S. FERENȚI, A. Ș. CICORT-LUCACIU, I. SAS (2012) Eryx jaculus (Reptilia, Boidae) north of the Danube: a road-killed specimen from Romania. Acta Herpetologica, 7 (1): 41-47.

GHERGHEL, I, M. PAPEŞ (2015) Landscape as a determinant of dispersal patterns and population connectivity in a newt species. Ecological Informatics, 28: 1-6.

GHERGHEL I., A. STRUGARIU, D. GHIURCĂ, A. Ș. CICORT-LUCACIU (2008) The herpetofauna from the Bistriţa River Basin (Romania): geographical distribution. North-Western Journal of Zoology, 4 (Suppl. 1): S71-S103.

GHIURCĂ, D., C. RANG, S. ROȘU (2005) Preliminary data concerning the herpetofauna in Bacău County. Universitatea din Bacău, Studii și Cercetari - Biologie, 11: 91-98.

GHIURCĂ, D., ROȘU, S., I. GHERGHEL (2005) Preliminary data concerning the herpetofauna in Neamț County (Romania). Analele Universității din Oradea, Fascicula Biologie, 12: 53-62.

GOMILLE, A. (2002) Die Äskulapnatter Elaphe longissima - Verbreitung und Lebensweise in Mitteleuropa. Frankfurt am Main: Edition Chimaira, 158 pp. (in German)

IFTIME, A. (2005) Elaphe longissima (Laurenti, 1768). P. 186. In: N. Botnariuc \& V. Tatole (eds.) Cartea Roșie a Vertebratelor din România. București, Muzeul Național de Istorie Naturală "Grigore Antipa".

MUSILOVA, R., V. ZAVADIL, P. KOTLIK (2007) Isolated populations of Zamenis longissimus (Reptilia: Squamata) above the northern limit of the continuous range in Europe: origin and conservation status. Acta Societatis Zoologicae Bohemicae, 71: 197-208. 
SAHLEAN, T.C., I. GHERGHEL, M. PAPEȘ, A. STRUGARIU, Ș. R. ZAMFIRESCU (2014) Refining Climate Change Projections for Organisms with Low Dispersal Abilities: A Case Study of the Caspian Whip Snake. PLoS One, 9(3): e91994.

SAHLEAN, T.C., V. D. GAVRIL, I. GHERGHEL, A. STRUGARIU (2015) Back in 30 years: A new record for the rare and highly elusive sand boa, Eryx jaculus turcicus (Reptilia: Boidae) in Romanian Dobruja. North-Western Journal of Zoology, 11 (2): 366-368.

STRUGARIU, A. (2014) Viperele (Reptilia: Viperidae) din estul României: ecologie, diversitate genetică şi conservare. PhD thesis - "Alexandru Ioan Cuza" University of Iași, Iași. (in Romanian)

STRUGARIU, A., I. GHERGHEL (2008) A preliminary report on the composition and distribution of the herpetofauna from the Lower Prut River Basin (Romania). North-Western Journal of Zoology, 4 (Suppl. 1): S49-S69.

STRUGARIU, A., T. C. SAHLEAN, M. V. HUȚULEAC-VOLOSCIUC, C. M. PUŞCAŞU (2006) Preliminary data regarding the distribution of reptilian fauna in Suceava County (Romania). North-Western Journal of Zoology 2 (1): 39-43.

STRUGARIU, A., Ș. R. ZAMFIRESCU, A. NICOARĂ, I. GHERGHEL, I. SAS, C. M. PUŞCAŞU, T. BUGEAC (2008) Preliminary data regarding the distribution and status of the herpetofauna in Iaşi County (Romania). North-Western Journal of Zoology 4 (Suppl. 1): S1-S23.

SZÉKELY, P., R. IOSIF, D. SZÉKELY, F. STǍNESCU, D. COGĂLNICEANU (2013) Range extension for the Eastern spadefoot toad Pelobates syriacus (Boettger, 1889) (Anura: Pelobatidae). Herpetology Notes, 6: 481-484. 
